"golden age" for working women, Ferrari emphasized the small number of independent female artisans in Southern towns and the precariousness of their economic existence. Even when listed in city directories as blacksmiths or shoemakers, Ferrari pointed out, most female artisans were merely managing their deceased husbands' slaves, who actually performed the work. The few women performing a trade did so largely in the clothing sector. While some female dressmakers enjoyed relative economic stability, retained their shops through marriage, widowhood, or remarriage, and often had access to considerable capital, most craftswomen, Ferrari stressed, found themselves in highly unstable and short-lasting positions. Thus, the author concluded, to a woman a "trade" often meant an added burden and not, as in the case of their male counterparts, a source of pride, identity, and relative economic stability.

\title{
New England Labor History Conference
}

\author{
Robert L. Cvornyek \\ Leslie Ann Schuster \\ Rhode Island College
}

The Forth Annual New England Labor History Conference, sponsored by the Blackstone River Valley National Heritage Corridor Commission and the University of Rhode Island's Labor Research Center, convened in Woonsocket, Rhode Island, April 2-3, 1993. Papers and events were aimed at a popular audience and included several reports of works in progress.

In the opening session, entitled "New England Mill Workers," Bruce Cohen presented "The Organization of the Garment Industry in Worcester, 1919-1950." He modified Worcester's reputation as an antiunion town by demonstrating the success of Jewish workers, mostly women, in organizing the city's garment trades, especially after 1923. Cohen traced the evolution of a seamless web of labor and community relations in the Jewish neighborhood bordering Water Street through the life of Daniel Goldman, a labor organizer turned garment manufacturer. In "The Corset Industry and its Employees in New Haven during the Gilded Age," Frank Annunziato analyzed the convergent effect of nineteenth-century industrial capitalism, paternalism, and Republican political dominance on labor relations in New Haven's corset industry. Although this expanding industry emerged as Connecticut's seventh-largest employer by 1890 , the mostly female and immigrant work force remained outside the fold of organized labor and under the "protective" eyes of industry operators. Mary 
Blewett's presentation raised two propositions regarding the general study of labor history. First, Blewett urged labor historians to study men and women industrial workers together, not separately, to discover the shifting meanings of gender, race, ethnicity, age and skill. Second, she emphasized the need for regional studies to capture workers' efforts to confront regionally based industries. For Blewett, the textile center of southeastern New England in the 1870 s offers an ideal opportunity to explore gender and ethnic divisions as well as to reconstruct the cultural and political experiences of a diverse work force.

The panel on labor peace and upheaval began with Timothy Coogan's paper, "Mill Town in Revolt: Adams and North Adams, 1850-1890s." Coogan demonstrated the dramatic transformations in class relations in Adams and North Adams in the years after the Civil War. With changes in industrial relations, a new class consciousness developed among textile and shoe workers and they turned to radical unionism and militant strikes to challenge employers. The middle class bemoaned the intensification of class relations and the passing of the paternalist order but by the $1880 \mathrm{~s}$ hostility had permeated labor relations. In "Cotton Chats: The Voice of the Draper Company, Hopedale, Massachusetts," Anita Danker explored the multiple functions of a turn-of-the-century company publication. The monthly circular Cotton Chats promoted Draper's product line while presenting the company as innovative and benevolent. It also reflected the company's efforts to advance mainstream values such as patriotism, faith in progress, and wartime vigilance, particularly among its immigrant work force. When a strike occurred in 1913 the publication became a forum to attack radical politics. Seth Wigderson examined "Judicial Strikebreaking in the 1937 Lewiston-Auburn Shoeworkers Strike." He demonstrated that elites in Maine-largely nativist, Yankee, and Republican-opposed New Deal protections for workers and unions by maintaining older forms of labor relations where jurisdiction over labor disputes lay with the judicial system. The 1937 strike illustrates how Maine's legal and political system insulated the state from New Deal legislation and continued to rely on the powerful weapon of judicial strikebreaking to defeat workers.

The last session focused on Rhode Island's labor force. Sara Errington explored the central role of language in both assimilation and cultural survival in "The Language Question: Nativism, Ethnicity, and Language Loyalty in Rhode Island, 1919-1925." In the 1920s, Rhode Island politicians and educators prohibited foreign-language instruction in schools in order to facilitate assimilation and limit subversive ideologies and strikes among ethnic groups. The language loyalty of French Canadians, however, remained strong, polarizing local politics and permitting Democrats to lure ethnic groups away from the Republican party. In "Factory Women and Girls of New England: The Chace Women and Cross-Class Reform Initiatives in the Gilded Age," Elizabeth Stevens examined the work of Elizabeth Buffum Chace, the daughter of a cotton manufacturer, and her daughter Lillie Chace Wyman, in improving the condition of the state's 
working women and addressing the exploitative factory system. Rather than aligning with their own economic class, the Chace women focused on the concerns of working women and criticized class distinctions for prohibiting middle-class women from also identifying with working women. For these women, ties to working women superseded class loyalties. Richard McIntyre and Shannon McLaughlin discussed their work in progress, "The Slave Trade and the Transition to Capitalism in Rhode Island, 1790-1820." They are documenting the extent to which slave trade profits contributed to early capital accumulation and industrialization in Rhode Island.

Finally, an evening presentation of the documentary Leather Soul was followed by an informal discussion led by Milton Cantor and featuring Bob Quin, producer, Joe Cultrera, director, and John Stanton, scriptwriter.

\title{
"Clio, Canons, and Culture": A Report on the 1993 Organization of American Historians Conference
}

\author{
David R. Finch \\ University of California, Los Angeles \\ Laurie C. Pintar \\ Emily Rader \\ University of Southern California
}

As the conference title suggests, cultural analysis was the focus of the eighty-sixth annual OAH meeting. Especially noteworthy were the numerous panels that examined popular culture and focused on a broad range of peoples. For example, in "Work-in-Progress Roundtable on American Indian History," James Riding-In discussed Pawnee cultural change and continuity, as well as popular representations of the Pawnee as "the bad guys" in movies such as Dances With Wolves. The papers presented in "Orientals,' Asians, and Asian Americans in American Culture," by Thomas Fujita and John Cheng, described stereotypes of Asians in comic books, movies, and popular novels during the first half of the twentieth century. Focusing on working-class Latino communities, Lorena Chambers, in "Work-in-Progress Roundtable on Latina History," analyzed the racial and sexual construction of beauty in newspaper advertising in Los Angeles in the late 1920s.

Although labor panels certainly included cultural analysis, the emphasis upon popular culture was less evident. Two significant exceptions to this included the presentations of Steven J. Ross in "Re-Imagining History: Alternative Visions of Class and Race in Film and Video," and Sumiko 